\title{
Sub-Saharan African Women's Views and Experiences of Risk Factors for Obstetric Fistula: A Qualitative Systematic Review
}

Lydia Babatunde Bulndi ( $\square$ lbabatun@our.ecu.edu.au )

Edith Cowan University

\section{Deborah Ireson}

Edith Cowan University

\section{Esther Adama}

Edith Cowan University

Sara Bayes

Australian Catholic University

\section{Research Article}

Keywords: Birth injury, Birth experiences, Obstetric fistula, Risk factors, Sub-Saharan Africa. Vesico Vagina Fistula, Women's views.

Posted Date: July 12th, 2021

DOI: https://doi.org/10.21203/rs.3.rs-611298/v1

License: () (1) This work is licensed under a Creative Commons Attribution 4.0 International License. Read Full License 


\section{Abstract}

Background: Obstetric fistula, also known as vesico vagina fistula (VVF), is a hole between the birth canal and the bladder or rectum caused by prolonged, obstructed labour. VVF may cause sufferers to experience chronic urinary and/or faecal incontinence, and the burden of continuing foul odour. Obstetric fistula is primarily caused by prolonged obstructed labour, which is brought about by a range of causes. Recently, it has been proposed that women's groups and fistula survivors should suggest interventions to reduce or resolve the incidence of VVF.

Objective: The objective of this review was to summarise what is reported about women's own views and experiences of the risk factors underlying the causes of obstetric fistula.

Methods: A systematic approach outlined in the Joanna Briggs institute Manual for Evidence synthesis was followed for this review, articles published within the last 11 years from 2011 to 2021 were selected against several criteria and critically appraised using JBI Critical Appraisal checklist for qualitative studies.

Results: Nine studies were retained for inclusion in this review, the data were then synthesised into five themes: (1) Cultural beliefs and practices impeding safe childbirth, (2) Lack of woman's autonomy in choices of place to birth safely, (3) Lack of accessibility and social support to safe childbirth, (4) Inexperienced birth attendants and, (5) Delayed emergency maternal care (childbirth).

Conclusions. This review highlights the complexity of risk factors predisposing women to the known causes of obstetric fistula. It also illuminates the absence of women's voices in the identification of solutions to these risks. Women are most directly affected by VVF. Therefore, their knowledge, views and experience should be considered in the development and implementation of strategies to address the issue. Exploring women's views on this issue would enable the identification of gaps in maternity care provision, which would be of interest to community and health service leaders as well as policy makers in Sub-Saharan Africa.

\section{Background}

Obstetric fistula, also known as vesico vagina fistula (VVF), is a hole between the birth canal and the bladder or rectum caused by prolonged obstructed labour. VVF may cause sufferers to experience chronic urinary and/or faecal incontinence, stigma of continuing foul odour, social exclusion, and decreased quality of life [1-3]. Obstetric fistula is primarily caused by prolonged obstructed labour, for which there are several known contributing factors. For example, giving birth at home in the absence of a midwife or skilled birth attendant can increase the likelihood of VVF [4].

According to the World Health Organisation [5], each year between 50,000 to 100,000 women worldwide are affected with obstetric fistula. Majority of women affected with VVF are from low income countries such as Sub-Saharan Africa, with under resourced ineffective health care systems [1]. In developed high-income countries, obstetric fistulas are rare and usually occur from injury to the bladder during gynaecologic procedures or radiation therapy [6].This disparity in incidence is likely due to sound midwifery and excellent birth skills being readily available to women in labour in developed countries [7, 8]. In low- and middle-income areas such as sub-Saharan Africa, however, VVF remains a public health concern [9-11] because of its far-reaching effects.

The consequences of VVF have a devastating impact on the lives of women, families, and communities $[1,12,13]$. The most immediate effect of VVF is that the woman experiences either single or double incontinence, which leads to social stigma and social isolation; it also has negative emotional health impacts such as psychological trauma and depression [14]. KD Cowgill, J Bishop, AK Norgaard, CE Rubens and MG Gravett [15] stated that there is a high rate of still birth among women who develop VVF, although the estimates of cases in which the two co-occur are variable and imprecise. Notwithstanding, the association between VVF and still birth is clear, with most women with VVF reporting a still birth [15]. The result for many women affected by obstetric fistula is that their key social roles such as that of mother, wife or daughter are lost, because they are unlikely to have a living child and are often abandoned by their husbands and wider family network $[1,16]$. Diminished capacity to socialise because of incontinence and its associated odour also occurs in women affected by obstetric fistula, which leads to decreased employability and financial hardship [1], resulting in erosion of self-worth and psychological distress [17-19]. Lastly, recurrent fistula is also a common complication of pregnancy among women previously affected by VVF, even after surgical repair of earlier injury [20, 21].

The multidimensional consequences of obstetric fistula require an understanding of women's experiences of risk factors to guide antenatal preparation of women for labour/ birth and intrapartum management of women [1]. Amodu and colleagues (2017) called for 
more research that involves community-oriented initiatives, where grassroots women's groups and fistula survivors suggest interventions that will reduce or resolve incidence of VVF in the communities. To begin to address this call, this review was conducted with the aim of identifying and synthesising recent qualitative studies on Sub-Saharan African women's views and experiences of risk factors associated with obstetric fistula occurrences and to determine any knowledge gap in the available literature on this topic.

\section{Review Question}

The specific review question was "What is the most recent qualitative evidence on Sub-Saharan African women's views and experiences of risk factors associated with obstetric fistula occurrences?".

\section{Methods}

\section{Design}

The process for conducting systematic reviews outlined in the Joanna Briggs institute Manual for Evidence synthesis [22, 23] was followed for this review. The process employed a thematic analysis (coding and categorising) process to synthesise the data reported in the included articles into themes [24, 25]. The PRISMA checklist [26] criteria were adhered to for this review and PICOS framework for reporting qualitative systematic reviews studies (Population, Phenomenon of interest, Context, Study design) was also adopted [27, 28] (see the Logic Grid in Table 1).

Table 1 Logic Grid: "What is the qualitative evidence on women's views and experiences of risk factors associated with obstetric fistula occurrences in Sub-Saharan African?"

\begin{tabular}{|llll|}
\hline Population & Phenomenon of Interest & Context & Study Design \\
\hline Women & $\begin{array}{l}\text { Perceptions of risk factors of obstetric fistula } \\
\text { Experiences of obstetric fistula }\end{array}$ & $\begin{array}{l}\text { Sub Saharan } \\
\text { Views of vesico- vaginal fistula } \\
\begin{array}{l}\text { Perspectives on recto-vesico-vaginal fistula } \\
\text { risks }\end{array}\end{array}$ & $\begin{array}{l}\text { Qualitative } \\
\text { Mixed method (qualitative data included } \\
\text { only) }\end{array}$ \\
\hline
\end{tabular}

\section{Inclusion And Exclusion Criteria}

Inclusion criteria for articles reviewed were: (i) primary research with qualitative or mixed method study designs, (ii) studies that included women of reproductive age, (iii) studies focusing on women's perspectives and experience of risk factors of VVF, (iv) peer reviewed studies published in English language (v) studies published between 2011-2021 and (vi) studies conducted only in SubSaharan Africa. Exclusion criteria included: (i) Studies focusing solely on consequences of obstetric fistula, (ii) Studies outside subSahara Africa, (iii) Studies focusing on awareness of risk factors of VVF, (iv) Quantitative studies.

\section{Search Strategy}

Four electronic databases (CINAHL, PubMed, Web of Science and Google Scholar) were searched to find recent articles (published within the last 11 years). Qualitative studies or mixed method studies with a qualitative component were sought. The initial database search was performed in September 2020, and a verification search was completed on 2nd March 2021. Keywords and NIH National Library of Medicine Medical Subjects' Heading (MeSH) [29] terms were combined for searching (Table 2). Boolean terms "AND" and "OR" were applied where appropriate to focus the search as much as possible (see Table 2). The reference lists of the retrieved articles were then hand searched to identify any additional studies that met the inclusion criteria.

Table 2: Final search string

Page 3/14 
The search string included: ("women's perception" [MeSH Terms]) OR ("women's view [MesH Terms]) OR ("women's experiences" [MeSH Terms]) OR ("women's perspectives" ([MeSH Terms]) AND ("risk factors" [MeSH Terms]) AND ("obstetric fistula" [MeSH

Terms]) OR ("vesico vagina fistula" [MeSH Terms]) OR ("recto vesico-vagina fistula" [ MeSH Terms]) AND ("Sub-Saharan African). "

\section{Study Selection And Quality Appraisal}


Table 3

Characteristics of Nine Qualitative/ Mixed Studies Reporting Risk Factors of Obstetrics Fistula in Sub Saharan Africa

\begin{tabular}{|c|c|c|c|c|c|c|c|}
\hline No & Authors & Title & Country & $\begin{array}{l}\text { Study design } \\
\text { /Methodology }\end{array}$ & $\begin{array}{l}\text { Sample } \\
\text { size/Participant }\end{array}$ & $\begin{array}{l}\text { Aim of the } \\
\text { study }\end{array}$ & Findings \\
\hline 1 & $\begin{array}{l}\text { Ahmed et al, } \\
2020\end{array}$ & $\begin{array}{l}\text { Childbirth } \\
\text { experiences } \\
\text { of Sudanese } \\
\text { women living } \\
\text { with obstetric } \\
\text { fistula }\end{array}$ & Sudan & $\begin{array}{l}\text { Qualitative/ } \\
\text { Thematic Analysis }\end{array}$ & $\begin{array}{l}19 \text { women, } \\
\text { semi -structure } \\
\text { interview }\end{array}$ & $\begin{array}{l}\text { The study } \\
\text { seeks to } \\
\text { provide a } \\
\text { better } \\
\text { understanding } \\
\text { of the } \\
\text { circumstances } \\
\text { surrounding } \\
\text { the occurrence } \\
\text { of Obstetric } \\
\text { Fistula. }\end{array}$ & $\begin{array}{l}\text { Family } \\
\text { members did } \\
\text { not allow the } \\
\text { women to go } \\
\text { to hospital for } \\
3 \text { day. Failure } \\
\text { of the birth } \\
\text { attendance to } \\
\text { recognise } \\
\text { danger signs } \\
\text { at home. }\end{array}$ \\
\hline 2 & $\begin{array}{l}\text { Bangser., } \\
2011\end{array}$ & $\begin{array}{l}\text { Childbirth } \\
\text { experiences } \\
\text { of women } \\
\text { with obstetric } \\
\text { fistula in } \\
\text { Tanzania and } \\
\text { Uganda and } \\
\text { their } \\
\text { implications } \\
\text { for fistula } \\
\text { program } \\
\text { development. }\end{array}$ & $\begin{array}{l}\text { Tanzania } \\
\text { and Uganda }\end{array}$ & $\begin{array}{l}\text { Mixed method/ } \\
\text { including } \\
\text { Participatory } \\
\text { approach }\end{array}$ & $\begin{array}{l}\text { Semi-structured } \\
\text { interviews, } \\
137 \text { women } \\
\text { Quantitative } \\
\text { survey }\end{array}$ & $\begin{array}{l}\text { Study } \\
\text { explores } \\
\text { whether } \\
\text { women's } \\
\text { experiences of } \\
\text { their "near- } \\
\text { miss" deaths } \\
\text { and } \\
\text { experiences } \\
\text { living with } \\
\text { fistula could } \\
\text { provide } \\
\text { essential } \\
\text { information } \\
\text { for } \\
\text { strengthening } \\
\text { maternal } \\
\text { health policies } \\
\text { and programs } \\
\text { and those } \\
\text { specifically } \\
\text { addressing } \\
\text { fistula. }\end{array}$ & $\begin{array}{l}\text { Participant } \\
\text { testimonies } \\
\text { expand } \\
\text { current } \\
\text { understanding } \\
\text { of women's } \\
\text { experience of } \\
\text { fistula. }\end{array}$ \\
\hline 3 & $\begin{array}{l}\text { Boene et al., } \\
2020\end{array}$ & $\begin{array}{l}\text { Obstetric } \\
\text { fistula in } \\
\text { southern } \\
\text { Mozambique: } \\
\text { a qualitative } \\
\text { study on } \\
\text { women's } \\
\text { experiences } \\
\text { of care } \\
\text { during } \\
\text { pregnancy, } \\
\text { delivery, and } \\
\text { post-partum } \\
\text { Northern } \\
\text { Nigeria. }\end{array}$ & Mozambique & $\begin{array}{l}\text { Qualitative } \\
\text { /phenomenological } \\
\text { approach }\end{array}$ & $\begin{array}{l}14 \text { Women in- } \\
\text { depth } \\
\text { interviews }\end{array}$ & $\begin{array}{l}\text { Describe } \\
\text { women's } \\
\text { experiences of } \\
\text { antenatal, } \\
\text { intrapartum, } \\
\text { and } \\
\text { postpartum } \\
\text { care in } \\
\text { southern } \\
\text { Mozambique, } \\
\text { to pinpoint } \\
\text { those } \\
\text { experiences } \\
\text { that are } \\
\text { unique to } \\
\text { women with } \\
\text { fistula to } \\
\text { understand } \\
\text { the care- } \\
\text { seeking and } \\
\text { care provision } \\
\text { circumstances } \\
\text { which could } \\
\text { have been } \\
\text { modified to } \\
\text { avoid or } \\
\text { mitigate the } \\
\text { onset or } \\
\text { consequences } \\
\text { of fistula. }\end{array}$ & $\begin{array}{l}\text { Deficiencies } \\
\text { and delays in } \\
\text { birth } \\
\text { assistance, } \\
\text { referral and } \\
\text { life-saving } \\
\text { interventions } \\
\text { were } \\
\text { commonly } \\
\text { reported by } \\
\text { women with } \\
\text { fistula }\end{array}$ \\
\hline
\end{tabular}




\begin{tabular}{|c|c|c|c|c|c|c|c|}
\hline No & Authors & Title & Country & $\begin{array}{l}\text { Study design } \\
\text { /Methodology }\end{array}$ & $\begin{array}{l}\text { Sample } \\
\text { size/Participant }\end{array}$ & $\begin{array}{l}\text { Aim of the } \\
\text { study }\end{array}$ & Findings \\
\hline 4 & $\begin{array}{l}\text { Changole et } \\
\text { al., } 2018\end{array}$ & $\begin{array}{l}\text { A road to } \\
\text { obstetric } \\
\text { fistula in } \\
\text { Malawi: } \\
\text { capturing } \\
\text { women's } \\
\text { perspectives } \\
\text { through a } \\
\text { framework of } \\
\text { three delays }\end{array}$ & Malawi & $\begin{array}{l}\text { Qualitative study/ } \\
\text { Social } \\
\text { constructivism } \\
\text { perspective and } \\
\text { interactionism }\end{array}$ & $\begin{array}{l}25 \text { women semi } \\
\text {-structure } \\
\text { interview. }\end{array}$ & $\begin{array}{l}\text { To understand } \\
\text { labour and } \\
\text { delivery } \\
\text { experiences of } \\
\text { women who } \\
\text { develop } \\
\text { obstetric } \\
\text { fistula in } \\
\text { Malawi. }\end{array}$ & $\begin{array}{l}\text { Finding } \\
\text { shows } \\
\text { decisions to } \\
\text { seek health } \\
\text { care when } \\
\text { labour is } \\
\text { complicated } \\
\text { were made by } \\
\text { mothers-in- } \\
\text { law and } \\
\text { traditional } \\
\text { birth } \\
\text { attendance. }\end{array}$ \\
\hline 5 & $\begin{array}{l}\text { Degge et al., } \\
2020\end{array}$ & $\begin{array}{l}\text { Insights from } \\
\text { birthing } \\
\text { experiences } \\
\text { of fistula } \\
\text { survivors in } \\
\text { north-central } \\
\text { Nigeria: } \\
\text { Interplay of } \\
\text { structural } \\
\text { violence }\end{array}$ & Nigeria & $\begin{array}{l}\text { Qualitative } \\
\text { study/Narrative } \\
\text { inquiry }\end{array}$ & $\begin{array}{l}15 \text { women, } \\
\text { Narrative } \\
\text { inquiry }\end{array}$ & $\begin{array}{l}\text { This study } \\
\text { examines the } \\
\text { social } \\
\text { structures } \\
\text { surrounding } \\
\text { the formation } \\
\text { of obstetric } \\
\text { fistula among } \\
\text { women. }\end{array}$ & $\begin{array}{l}\text { The study } \\
\text { evidenced } \\
\text { obstetric } \\
\text { fistula, as a } \\
\text { product of } \\
\text { structural } \\
\text { violence } \\
\text { occurring in a } \\
\text { country with } \\
\text { poor health } \\
\text { system. }\end{array}$ \\
\hline 6 & $\begin{array}{l}\text { Kaplan et al., } \\
2017\end{array}$ & $\begin{array}{l}\text { An } \\
\text { investigation } \\
\text { of the } \\
\text { relationship } \\
\text { between } \\
\text { autonomy, } \\
\text { childbirth } \\
\text { practices, } \\
\text { and obstetric } \\
\text { fistula } \\
\text { among } \\
\text { women in } \\
\text { rural } \\
\text { Lilongwe } \\
\text { district, } \\
\text { Malawi }\end{array}$ & Malawi & $\begin{array}{l}\text { Qualitative study/ } \\
\text { Grounded theory }\end{array}$ & $\begin{array}{l}25 \text { women, in } \\
\text { depth } \\
\text { qualitative } \\
\text { interview }\end{array}$ & $\begin{array}{l}\text { This study } \\
\text { assessed } \\
\text { whether } \\
\text { women's } \\
\text { limited } \\
\text { autonomy in } \\
\text { rural Malawi } \\
\text { reinforces } \\
\text { childbearing } \\
\text { practices that } \\
\text { increase risk } \\
\text { of obstetric } \\
\text { fistula. }\end{array}$ & $\begin{array}{l}\text { Study shown } \\
\text { women are } \\
\text { required to } \\
\text { seek } \\
\text { permission } \\
\text { from husband } \\
\text { to visit the } \\
\text { antenatally } \\
\text { clinic and } \\
\text { labour ward. }\end{array}$ \\
\hline 7 & $\begin{array}{l}\text { Mwini- } \\
\text { Nyaledzigbor } \\
\text { et al., } 2013\end{array}$ & $\begin{array}{l}\text { Lived } \\
\text { experiences } \\
\text { of Ghanaian } \\
\text { women with } \\
\text { obstetric } \\
\text { fistula. }\end{array}$ & Ghana & $\begin{array}{l}\text { Qualitative } \\
\text { study/Descriptive } \\
\text { approach }\end{array}$ & $\begin{array}{l}10 \text { women, } \\
\text { semi structured } \\
\text { interviews }\end{array}$ & $\begin{array}{l}\text { Explores the } \\
\text { experiences of } \\
\text { Ghanaian } \\
\text { women who } \\
\text { sustained } \\
\text { obstetric } \\
\text { fistula during } \\
\text { childbirth. }\end{array}$ & $\begin{array}{l}\text { Study shows } \\
\text { the } \\
\text { combination } \\
\text { of poor status, } \\
\text { lack of } \\
\text { education, } \\
\text { and poor } \\
\text { access to } \\
\text { healthcare } \\
\text { facility lead to } \\
\text { fistula. }\end{array}$ \\
\hline 8 & $\begin{array}{l}\text { Mselle et al., } \\
2011\end{array}$ & $\begin{array}{l}\text { Waiting for } \\
\text { attention and } \\
\text { care: birthing } \\
\text { accounts of } \\
\text { women in } \\
\text { rural } \\
\text { Tanzania } \\
\text { who } \\
\text { developed } \\
\text { obstetric } \\
\text { fistula as an } \\
\text { outcome of } \\
\text { labour }\end{array}$ & Tanzania & $\begin{array}{l}\text { Qualitative and } \\
\text { Quantitative } \\
\text { Study/Survey and } \\
\text { interpretative } \\
\text { approach }\end{array}$ & $\begin{array}{l}16 \text { women } \\
\text { semi-structured } \\
\text { interview, } 151 \\
\text { quantitative } \\
\text { survey }\end{array}$ & $\begin{array}{l}\text { To use both } \\
\text { qualitative } \\
\text { and } \\
\text { quantitative to } \\
\text { explore the } \\
\text { birthing } \\
\text { experiences of } \\
\text { women } \\
\text { affected by } \\
\text { obstetric } \\
\text { fistula, and } \\
\text { barriers to } \\
\text { accessing } \\
\text { adequate } \\
\text { quality of care } \\
\text { during labour } \\
\text { and delivery. }\end{array}$ & $\begin{array}{l}\text { Study reveals } \\
\text { a series of } \\
\text { weaknesses } \\
\text { in the health } \\
\text { care system } \\
\text { associated } \\
\text { with obstetric } \\
\text { competence, } \\
\text { infrastructure, } \\
\text { and health } \\
\text { worker - } \\
\text { women } \\
\text { relationship }\end{array}$ \\
\hline
\end{tabular}




\begin{tabular}{|c|c|c|c|c|c|c|c|}
\hline No & Authors & Title & Country & $\begin{array}{l}\text { Study design } \\
\text { /Methodology }\end{array}$ & $\begin{array}{l}\text { Sample } \\
\text { size/Participant }\end{array}$ & $\begin{array}{l}\text { Aim of the } \\
\text { study }\end{array}$ & Findings \\
\hline 9 & $\begin{array}{l}\text { Mselle et al., } \\
2015\end{array}$ & $\begin{array}{l}\text { Perceived } \\
\text { health care } \\
\text { system } \\
\text { causes of } \\
\text { obstetric } \\
\text { fistula from } \\
\text { accounts of } \\
\text { affected } \\
\text { women in } \\
\text { rural } \\
\text { Tanzania a } \\
\text { qualitative } \\
\text { study }\end{array}$ & Tanzania & $\begin{array}{l}\text { Qualitative study } \\
\text { /Thematic Analysis }\end{array}$ & $\begin{array}{l}16 \text { women semi } \\
\text {-structured } \\
\text { interviews, } \\
12 \text { focus group }\end{array}$ & $\begin{array}{l}\text { The study } \\
\text { aimed at } \\
\text { exploring and } \\
\text { describing } \\
\text { perceived } \\
\text { health system } \\
\text { causes of } \\
\text { obstetric } \\
\text { fistula from } \\
\text { women } \\
\text { Affected. }\end{array}$ & $\begin{array}{l}\text { Women's } \\
\text { perceptions } \\
\text { emphasize } \\
\text { the } \\
\text { importance of } \\
\text { improving the } \\
\text { quality of } \\
\text { obstetric care } \\
\text { provided by } \\
\text { health care } \\
\text { facility. }\end{array}$ \\
\hline
\end{tabular}

\section{Data Analysis And Synthesis}

Inductive thematic analysis was used to analyse and synthesise the data using the approach described by $\mathrm{J}$ Thomas and A Harden [25]. Three stages are involved in this approach, which allows clear identification of themes from extracted data in qualitative studies. These stages are: (I) coding the selected studies (ii) developing descriptive themes from the codes to aggregate similar ideas (iii) generating analytic or more abstract themes. The findings of each included study were extracted and reviewed line by line to assign codes which were then grouped into descriptive themes. Finally, analytical themes were developed. The first author analysed all data, and authors 2-4 each analysed a selection of data; all data were analysed by two people independently. All authors then came together to reach consensus about the final themes.

\section{Results}

Five descriptive themes were identified in the included articles; these were then synthesised to form five analytical themes (see Table 4). The five analytical themes are described below.

Table 4

Descriptive and analytical themes.

\begin{tabular}{|c|c|}
\hline Descriptive Theme & Analytical Theme \\
\hline Cultural beliefs and practices of traditional birth attendants (TBA) & Cultural beliefs and practices impeding safe childbirth \\
\hline Inability of women to make decisions related to safe childbirth. & $\begin{array}{l}\text { Lack of woman's autonomy in choices of place to birth } \\
\text { safely. }\end{array}$ \\
\hline $\begin{array}{l}\text { Lack of transportation, financial hardships, and absence of social } \\
\text { support. }\end{array}$ & Lack of accessibility and social support for safe childbirth \\
\hline Poorly skilled attendants & Inexperienced skilled birth attendant \\
\hline Poorly assisted health facility childbirth (Vacuum or Forceps). & Delayed emergency maternal care (childbirth) \\
\hline
\end{tabular}

Theme 1 Cultural beliefs and practices impeding safe childbirth.

Three articles cited cultural beliefs and practices as a risk factor expressed by women for the cause of obstetric fistula. [31-33].These articles reported cultural beliefs and practices impeded safe childbirth reporting outcomes including obstetric fistula and foetal death. Some of the cultural beliefs and practices included unskilled birth attendants such as matriarchal figures and traditional birth attendants rather than qualified midwives. First time mothers or primiparous women were asked by relatives to wait at home and birth with unskilled birth attendants who have little or no physiological understanding of labour and birth. Other cultural practices include asking women to confess an adultery act to pacify the gods for safe birthing. One participant related to this in the following quotation: "I was in labor from night to the following day evening and I was in pain and tired, but instead of taking me to the hospital, they rather suspected that I had committed adultery and that was why the labour was difficult. The old women [TBA] insisted that I confess to enable the baby to come out. But I also insisted on my innocence. Not convinced by that, they went and had some consultations with their gods and offered some sacrifices" [33] 
Theme 2 Lack of women's autonomy in choices of place to birth safely.

Women's lack of negotiating power and ready acceptance of other's decisions were reported in four studies [31, 33-35]. This theme shows that women are not consulted in decision making concerning the choice of healthcare or place of birth but instead a male guardian, traditional birth attendants, husband or father take patriarchal authority. For example, one woman discussed this factor in relation to the development of VVF as follows: "I was in labour pains for three days at home with a traditional birth attendant. I didn't think about going to the hospital since my family would not allow me to go to the hospital because they say women who deliver for the first time should wait and be patient"[31].

\section{Theme 3 Lack of accessibility and social support for safe childbirth.}

Findings from seven studies highlighted this theme $[4,31,32,34-37]$ in which women expressed difficulty in accessing health care facilities because of distance, poor roads, lack of finances and lack of suitable transportation (including delays in hire vehicles and/or lack of finances to hire a vehicle). For instance, one woman described her experience as follows: "The hospital is far therefore, it took some time to find the money to rent a car to take me there, it took us a whole day to reach the hospital, on reaching the hospital, they put me up on the delivery table, but they told me that the baby had died" [31]. Poverty impeded access to healthcare and planning for the care needed when women are in labour as expressed by a woman who related her VVF to "I plan to deliver at the hospital but it was not possible because I did not have cash and I did not know where I will get money from, it was January, during the farming season, I did not go to the field, my husband went, I did not go, and it was then that I got these problems" [35]. Lack of social support from (friends or family) to convey the parturient woman to a health facility was also reported: "Labour pains started suddenly around midnight, and I started off for the hospital. But since I was all alone and walking slowly struggling along the way due to labour pains, it took time. But if only I had someone, to take me on a bicycle, maybe I would have gotten to the hospital in time. So, while I was on the way to the hospital, my legs got cold; were numb, I could no longer walk. So, I thought of just sitting down. Then I just saw that legs have started coming out. I said "ah! ...ah!, what is this ?" I tried to stand, but I could not manage. So just remained seated, all alone. So, I just remained seated, all alone. So when the thing [ baby] finally stretched its legs and came out, I saw that the thing was already dead [Nangozo, 13 years living with fistula] [36].

\section{Theme 4 Inexperienced birth attendant.}

Aggregation of findings from three studies made up this theme $[31,32,36]$. Women's previous encounters with inexperienced and neglectful healthcare providers during childbirth was cited as an indirect risk factor of VVF. Women perceived young skilled birth attendants as inexperienced in providing quality obstetric care as compared to mature TBAs. This potentially inaccurate perception of skilled birth attendants and the TBA's lack of knowledge and skills in managing obstructed labour can result in the development of VVF. One woman recalled: "At the hospital nowadays there are many small children [young midwives] who attend to you, so you think to yourself "ah, it is better to go to that old woman to help me, moreover, at the hospital they are not even there to receive your baby when it is coming, you do the work [push] by yourself and call them when the baby is out, while at the Azamba [TBA], she is always there" [36].These perceptions about skilled birth attendants as lead many women to seeking care from traditional birth attendants who lack knowledge in recognising obstructed labour (Changole et al., 2018)

\section{Theme 5 Delayed Emergency Maternal Care (Childbirth)}

This theme was obtained from the analysis of findings from three articles $[16,35,37]$. This theme shows that delays in receiving emergency care on reaching a health care facility constitute risk for the development of VVF among women of childbearing age. Lack of essential emergency services associated with shortage of staff or equipment, including delay in referring women to health care facilities with available emergency services was highlighted. As an example, one woman related the development of her VVF to the following scenario: "I was in labour for a long time while in the hospital, labour pain comes and goes and each time when you call, nurses tell you, wait, though I had very strong pains. I didn't see the reason as to why I could not be sent for operation early...I think nurses contributed to my problem". [37]

\section{Discussion}

This study synthesised the qualitative findings of nine studies to understand Sub-Saharan African women's views and experiences of risk factors for obstetric fistula. Five analytical themes were identified: 'Cultural beliefs and practices impeding safe childbirth, lack of woman's autonomy to choices of place to birth safely, lack of accessibility and social support to safe childbirth, inexperienced birth 
attendant and delayed emergency maternal care services in childbirth; all these themes represent what is currently known about what women's views are and their experiences of risk factors underlying the causes of obstetric fistula in Sub-Saharan African.

Our findings highlighted how cultural beliefs and practices impede women from seeking skilled childbirth attendants. The fact that some women do give birth successfully in the context of such beliefs at home with a traditional birth attendant (TBA) has reinforced this approach in the community; however, the focus on spiritual and magical drivers of labour and birth put reproductive women at risk of obstetric fistula and/or stillbirth [33]. As J Changole, V Combs Thorsen and U Kafulafula [36] asserted, TBAs' lack of understanding of birth physiology and the nature, meaning and impact of prolonged or obstructed labour is crucial in the development of VVF. The result is that women are kept at home for an extended period before referral to the hospital; in some cases, they are never referred to the hospital even when complications are evident [38]. However a contrast to this pattern was reported in the Ethiopian health care system, where TBAs' role was acknowledged as that of a volunteer worker, attending to women under the supervision of health extension workers; although the role and relationship has not been clearly defined [39]. This approach could seem to be a safer approach that TBAs who lack knowledge of anatomy, physiology, and pathophysiology education leading women's intrapartum care. Programmes that incorporate a participatory approach such as that outlined by Shiferaw and team (2013) seem to offer a model of care for women in labour where TBAs are given well-defined roles such as birth companions or interpreters for women in labour [40]. Midwives currently working in communities can be a useful resource for training TBAs to a competent level with a well-defined role this will improve health care services to meet the needs of rural women and family needs [40]. However, it is essential that provision of childbirth care,

preferences and needs including having a companion of choices in labour be considered by midwives and other skilled birth attendants to reduce risk of VVF in the community [40-42]

Our review also elucidates limited decision-making power on the part of women regarding where to give birth. This choice is primarily made by the woman's husband, mother, the TBAs, her mother-in-law, grandmothers, or other relations instead of the women [31, 33-35]. The data in the articles we reviewed concurs with a study undertaken at Sokoto Northern Nigeria [43] in which it was found that low patronage of modern maternal health facilities by women in labour was associated with limitations placed on women's freedom to choose the health care centre as a place to birth safely. In this study, women could not access healthcare services without the permission of their husbands [43]. In Malawi, women's lack of access to financial resources are implicated in this issue as this leads directly to women having limited autonomy on health care utilisation during labour and birth, which in turn increases their risk of developing VVF [34]. In Northern Nigeria, the factors underlying lack of decision making power is similar: it is related to the practice of "Purdah", which involves wife seclusion whereby women are not allowed to go out to earn a living [14].

We also found issues of lack of accessibility and social support for safe childbirth environments, as few women have either available means of transportation, support from husbands and relations in accompanying them to health institutions when they are in active labour, or the ability to afford medical supplies required by hospitals $[16,31,32,36]$. Transportation is costly and unaffordable, or it is non-existent [38, 44, 45]. This finding is in line with that of HM Degge, $M$ Laurenson, EW Dumbili and $M$ Hayter [32], who described lack of transportation for women in labour as structural violence against women. L Barbi, M Cham, E Ame-Bruce and M Lazzerini [46] also implicated cost as a barrier to safe birthing environment and another reason for why women seek traditional birth attendants' services rather than birth in a health facility, is because women are asked to bring medical supplies or consumables that they cannot afford; in contrast TBAs require nothing but a white piece of cloth. Pregnancy and childbirth issues in African countries are perceived to be "women's issues", and most men are culturally excluded from participating in maternal care or in accompanying their partner to clinic $[36,47]$. However, FK Ongolly and SA Bukachi [47] study mirrored that, even though men are culturally excluded in maternal care, some men still want to be involved in healthcare issues of their spouses at critical times such as decision making but were given little or no attention by the midwives at the clinic, therefore some men thought it to be time wasting accompanying their spouse in labour to the clinic.

Another factor we identified in women developing obstetric fistula in this review, is women's reluctance to attend dedicated maternity care facilities secondary to a lack of trust in those facilities' care givers' and inexperienced encountered at places of parturition [48, 49]. Women's choice of place to birth was shaped by their negative past experiences with health care facility during childbirth and their recall of health care providers as incompetent in handling their labour [36, 39, 44, 50, 51]. A Philibert, V Ridde, A Bado and P Fournier [52] suggests that a shortage of skilled experienced staff in the maternity units, or limited professional development might be reasons for skilled birth attendants' limited exposure to (and therefore limited competence in managing) the array of complications they might be presented with, as well as increased workload or deteriorating staff morale. In contrast to our finding, S Mocumbi, U Högberg, E Lampa, C Sacoor, A Valá, A Bergström, P von Dadelszen, K Munguambe, C Hanson, E Sevene, et al. [53] reported increased satisfaction 
of care received during childbirth among women in a dedicated maternity care facility. The researchers related the women's satisfaction to the availability of qualified human resources including highly qualified midwives in the facility.

Finally, this review also highlighted delayed emergency maternal care services as an indirect cause of VVF. Lack of essential emergency services associated with shortage of staff or equipment, including delay in referring women to health care facility with emergency services such as emergency caesarean section was experienced at healthcare facility $[16,35,37]$. This is in agreement with a study conducted in Uganda which report lack of essential emergency obstetric services in the cases of emergency including a lack of functional referral system [50]. Women attribute lack of essential emergency services as an indirect cause of VVF including delay in referring women to health care facility with emergency services.

\section{Strengths and limitations of the review.}

The objective of this review, which was to report what is currently known about "Sub-Saharan African women's views and experiences of risk factors for obstetric fistula", and to highlight gaps in knowledge about this topic, was fulfilled. One of the limitations is that the period of inclusion (2011-2021) may mean that earlier publications that might have yielded useful insights were not included. Secondly, the search was limited to articles published in English language, and the omission of studies reported in other languages, particularly African languages, might have excluded useful data. Thirdly, grey literature, which may have provided additional insights into this topic, were excluded.

\section{Implications for practice and Policy}

- Future policies and initiatives should focus on culturally sensitive care which will corporate participatory approach for women in labour where TBAs will be given well- defined roles such as birth companions or interpreters for women in labour.

- There is need to develop compressive strategies that is inclusive such as building more maternity to cater for women within the community to meet the needs of women in labour.

- Policy that encourages male involvement during labour are potential interventions to increase male involvement in pregnancy and childbirth issues.

- There is need to train more midwifes with the necessary skills required to prevent VVF through continuous midwifery programmes.

\section{Conclusion}

This review synthesised current qualitative findings of nine studies to understand Sub-Saharan African women's views and experiences of risk factors for obstetric fistula. Cultural beliefs and practices impeding safe childbirth, lack of woman's autonomy to choices of place to birth safely, lack of accessibility and social support to safe childbirth, inexperienced birth attendant and delayed emergency maternal care services in childbirth together conspire to fistula formation. Although it is evident in the research published on this topic that women are well able to state what the factors underlying VVF are, it cannot be assumed that this review captures them all or that addressing these factors would mean a reduction in the incidence of VVF. To address the issue of VVF in Sub-Saharan Africa, further research is needed in the identification of solutions to these risks. Women are most directly affected by VVF. Therefore, their knowledge, views and experiences should be considered in the development and implementation of strategies to address the issue. Research that is focused sharply on capturing all the issues that are implicated in VVF, and women's proposed solutions to those issues, is warranted. Exploring women's views on this issue would enable the development of remedial strategies, which would be of interest to community and health service leaders as well as to policy makers in Sub-Saharan Africa.

\section{Abbreviations}

VVF-Vesico Vaginal Fistula; JBI- Joanna Briggs institute; PRISMA-Preferred Reporting Items for Systematic review and Meta-Analyses; PICOS- Population or Phenomenon of interest Context Study designs; TBAs- Traditional Birth Attendance(s)

\section{Declarations}

\section{Ethics declarations}

Ethics approval and consent to participate. 
Not applicable.

\section{Consent for publication}

Not applicable

Availability of data and materials

Data sharing is not applicable to this article as no dataset were generated or analysed during the current study.

\section{Competing interests}

The authors declare that they have no competing interests.

\section{Funding}

This work was funded by an Edith Cowan University Australia

\section{Author's contributions.}

The manuscript was drafted by L.B.B with substantial contributions made by D.I and E.A in the selection and assessment of the quality of the included articles with S.B critically reviewed the manuscript and resolved all differences. All the authors contributed significantly to the drafting of the manuscript and reviewed the manuscript and approved the manuscript for submission.

\section{Author's details}

1,2Edith Cowan University, 270 Joondalup Drive, Joondalup, Western Australia 6027, Australia.

1, 2 The Centre Evidence Informed Nursing, Midwifery and Health Care Practice: A JBI Affiliated Group

1,2, 3 School of Nursing, Midwifery, and paramedicine (Melbourne), Australian Catholic University, 115 Victoria Parade Fitzroy Vic 3065, Australia.

\section{Acknowledgements}

We would like to forward our appreciation to Lisa Webb for your valuable advice given to us.

\section{References}

1. Bashah DT, Worku AG, Mengistu MY: Consequences of obstetric fistula in sub Sahara African countries, from patients' perspective: a systematic review of qualitative studies. BMC Women's Health 2018, 18(1):106.

2. Lufumpa $E$, Doos L, Lindenmeyer A: Barriers and facilitators to preventive interventions for the development of obstetric fistulas among women in sub-Saharan Africa: a systematic review. BMC Pregnancy and Childbirth 2018, 18(1):155.

3. Mohamed AA, llesanmi AO, Dairo MD: The Experience of Women with Obstetric Fistula following Corrective Surgery: A Qualitative Study in Benadir and Mudug Regions, Somalia. Obstetrics and gynecology international 2018, 2018.

4. Bangser M, Mehta M, Singer J, Daly C, Kamugumya C, Mwangomale A: Childbirth experiences of women with obstetric fistula in Tanzania and Uganda and their implications for fistula program development. International Urogynecology Journal 2011, 22(1):91-98.

5. 10 Facts on obstetric fistula [https://www.who.int/features/factfiles/obstetric_fistula/en/]

6. Polan ML, Sleemi A, Bedane MM, Lozo S, Morgan MA: Obstetric fistula. In., edn.; 2015.

7. Joseph G, da Silva ICM, Wehrmeister FC, Barros AJD, Victora CG: Inequalities in the coverage of place of delivery and skilled birth attendance: analyses of cross-sectional surveys in 80 low and middle-income countries. Reproductive Health 2016, 13(1):77.

8. World Health Organization: Proportion of births attended by a skilled attendant: 2008 updates. In.: World Health Organization; 2008. 
9. Capes T, Ascher-Walsh C, Abdoulaye I, Brodman M: Obstetric Fistula in Low and Middle Income Countries. Mount Sinai Journal of Medicine: A Journal of Translational and Personalized Medicine 2011, 78(3):352-361.

10. Swain D, Parida SP, Jena SK, Das M, Das H: Prevalence and risk factors of obstetric fistula: implementation of a need-based preventive action plan in a South-eastern rural community of India. BMC Women's Health 2020, 20(1):40.

11. Lombard L, de St. Jorre J, Geddes R, El Ayadi AM, Grant L: Rehabilitation experiences after obstetric fistula repair: systematic review of qualitative studies. Tropical Medicine \& International Health 2015, 20(5):554-568.

12. Mafo Degge $H$, Hayter $M$, Laurenson M: An integrative review on women living with obstetric fistula and after treatment experiences. Journal of Clinical Nursing 2017, 26(11-12):1445-1457.

13. Tembo NN, Kwaleyela C, Mukwatokatowa P, Odland J, Zulu JM, Maimbolwa MC: Marital experiences of women with obstetric fistula: a systematic review of qualitative studies. African Journal of Midwifery and Women's Health 2020, 14(1):1-13.

14. Amodu OC, Salami B, Richter S: Obstetric fistula and sociocultural practices in Hausa community of Northern Nigeria. Women and Birth 2017, 30(5):e258-e263.

15. Cowgill KD, Bishop J, Norgaard AK, Rubens CE, Gravett MG: Obstetric fistula in low-resource countries: an under-valued and understudied problem - systematic review of its incidence, prevalence, and association with stillbirth. Bmc Pregnancy and Childbirth 2015, 15.

16. Boene H, Mocumbi S, Högberg U, Hanson C, Valá A, Bergström A, Sevene E, Munguambe K: Obstetric fistula in southern Mozambique: a qualitative study on women's experiences of care pregnancy, delivery and post-partum. Reproductive Health 2020, 17(1):21.

17. Khisa W, Wakasiaka S, McGowan L, Campbell M, Lavender T: Understanding the lived experience of women before and after fistula repair: a qualitative study in Kenya. BJOG: An International Journal of Obstetrics \& Gynaecology 2017, 124(3):503-510.

18. Weston K, Mutiso S, Mwangi JW, Qureshi Z, Beard J, Venkat P: Depression among women with obstetric fistula in Kenya. International Journal of Gynecology \& Obstetrics 2011, 115(1):31-33.

19. Zeleke BM, Ayele TA, Woldetsadik MA, Bisetegn TA, Adane AA: Depression among women with obstetric fistula, and pelvic organ prolapse in northwest Ethiopia. BMC psychiatry 2013, 13(1):236.

20. Ahmed S, Anastasi E, Laski L: Double burden of tragedy: stillbirth and obstetric fistula. The Lancet Global Health 2016, 4(2):e80e82.

21. Nsambi J, Mukuku O, Kakudji P, Kakoma JB: Model predicating failure in surgical repair of obstetric vesicovaginal fistula. Pan African Medical Journal 2019, 34.

22. Aromataris E, Fernandez R, Godfrey CM, Holly C, Khalil H, Tungpunkom P: Summarizing systematic reviews: methodological development, conduct and reporting of an umbrella review approach. International journal of evidence-based healthcare 2015, 13(3):132-140.

23. Aromataris E, Pearson A: The Systematic Review: An Overview. AJN The American Journal of Nursing 2014, 114(3):53-58.

24. Butler A, Hall H, Copnell B: A Guide to Writing a Qualitative Systematic Review Protocol to Enhance Evidence-Based Practice in Nursing and Health Care. Worldviews on Evidence-Based Nursing 2016, 13(3):241-249.

25. Thomas J, Harden A: Methods for the thematic synthesis of qualitative research in systematic reviews. $B M C$ medical research methodology 2008, 8(1):45.

26. Page MJ, McKenzie JE, Bossuyt PM, Boutron I, Hoffmann TC, Mulrow CD, Shamseer L, Tetzlaff JM, Moher D: Updating guidance for reporting systematic reviews: development of the PRISMA 2020 statement. Journal of Clinical Epidemiology 2021, 134:103112.

27. Methley AM, Campbell S, Chew-Graham C, McNally R, Cheraghi-Sohi S: PICO, PICOS and SPIDER: a comparison study of specificity and sensitivity in three search tools for qualitative systematic reviews. BMC Health Serv Res 2014, 14:579-579.

28. Robinson KA, Saldanha IJ, Mckoy NA: Development of a framework to identify research gaps from systematic reviews. Journal of clinical epidemiology 2011, 64(12):1325-1330.

29. Tait M: LibGuides: APA 7th Edition Referencing Guide1: Databases/online. 2019.

30. Lockwood C, Munn Z, Porritt K: Qualitative research synthesis: methodological guidance for systematic reviewers utilizing metaaggregation. International journal of evidence-based healthcare 2015, 13(3):179-187.

31. Ahmed SAE, Wangamati CK, Thorsen VC: Childbirth experiences of Sudanese women living with obstetric fistula - A qualitative study. Sexual \& Reproductive Healthcare 2020, 25:100532.

Page 12/14 
32. Degge HM, Laurenson M, Dumbili EW, Hayter M: Insights from birthing experiences of fistula survivors in North-central Nigeria: Interplay of structural violence. Nursing Inquiry 2020, 27(4).

33. Mwini-Nyaledzigbor PP, Agana AA, Pilkington FB: Lived experiences of Ghanaian women with obstetric fistula. Health care for women international 2013, 34(6):440-460.

34. Kaplan JA, Kandodo J, Sclafani J, Raine S, Blumenthal-Barby J, Norris A, Norris-Turner A, Chemey E, Beckham JM, Khan Z et al: An investigation of the relationship between autonomy, childbirth practices, and obstetric fistula among women in rural Lilongwe District, Malawi. BMC International Health and Human Rights 2017, 17(1):17.

35. Mselle LT, Kohi TW, Mvungi A, Evjen-Olsen B, Moland KM: Waiting for attention and care: birthing accounts of women in rural Tanzania who developed obstetric fistula as an outcome of labour. BMC pregnancy and childbirth 2011, 11:75.

36. Changole J, Combs Thorsen V, Kafulafula U: A road to obstetric fistula in Malawi: capturing women's perspectives through a framework of three delays. In: International Journal of Women's Health. vol. 10; 2018: 699-713.

37. Mselle, T. L, Kohi, W. T: Perceived Health System Causes of Obstetric Fistula from Accounts of Affected Women in Rural Tanzania: A Qualitative Study. African Journal of Reproductive Health 2015, 19(1):124-132.

38. Molzan Turan J, Johnson K, Lake Polan M: Experiences of women seeking medical care for obstetric fistula in Eritrea: implications for prevention, treatment, and social reintegration. Global public health 2007, 2(1):64-77.

39. Shiferaw S, Spigt M, Godefrooij M, Melkamu Y, Tekie M: Why do women prefer home births in Ethiopia? BMC Pregnancy and Childbirth 2013, 13(1):5.

40. Miller, Tina, Smith, Helen: Establishing partnership with traditional birth attendants for improved maternal and newborn health: a review of factors influencing implementation. BMC Pregnancy and Childbirth 2017, 17(1):365.

41. Imogie AO, Agwubike EO, Aluko K: Assessing the Role of Traditional Birth Attendants (TBAs) in Health Care Delivery in Edo State, Nigeria. African Journal of Reproductive Health / La Revue Africaine de la Santé Reproductive 2002, 6(2):94-100.

42. Lane, K., Garrod, J.: The return of the Traditional Birth Attendant. J Glob Health 2016, 6(2):020302.

43. Shamaki MA, Buang A: The Socio-cultural Behaviours of Women's Health Facilities Utilisation in Northern Nigeria, vol. 6; 2015.

44. Baker Z, Bellows B, Bach R, Warren C: Barriers to obstetric fistula treatment in low-income countries: a systematic review. Tropical Medicine \& International Health 2017, 22(8):938-959.

45. Lazzerini M, Barbi E, Apicella A, Marchetti F, Cardinale F, Trobia G: Delayed access or provision of care in Italy resulting from fear of COVID-19. The Lancet Child \& Adolescent Health 2020, 4(5):e10-e11.

46. Barbi L, Cham M, Ame-Bruce E, Lazzerini M: Socio-cultural factors influencing the decision of women to seek care during pregnancy and delivery: A qualitative study in South Tongu District, Ghana. Global Public Health 2020:1-14.

47. Ongolly FK, Bukachi SA: Barriers to men's involvement in antenatal and postnatal care in Butula, western Kenya. African journal of primary health care \& family medicine 2019, 11(1):1-7.

48. Bradley S, McCourt C, Rayment J, Parmar D: Disrespectful intrapartum care during facility-based delivery in sub-Saharan Africa: A qualitative systematic review and thematic synthesis of women's perceptions and experiences. Social Science \& Medicine 2016 , 169:157-170.

49. Galle A, Manaharlal H, Cumbane E, Picardo J, Griffin S, Osman N, Roelens K, Degomme O: Disrespect and abuse during facilitybased childbirth in southern Mozambique: a cross-sectional study. BMC pregnancy and childbirth 2019, 19(1):1-13.

50. Anastasi E, Borchert M, Campbell OMR, Sondorp E, Kaducu F, Hill O, Okeng D, Odong VN, Lange IL: Losing women along the path to safe motherhood: why is there such a gap between women's use of antenatal care and skilled birth attendance? A mixed methods study in northern Uganda. BMC Pregnancy and Childbirth 2015, 15(1):287.

51. Idris S, Sambo M, Ibrahim M: Barriers to utilisation of maternal health services in a semi-urban community in northern Nigeria: The clients' perspective. Nigerian Medical Journal 2013, 54(1):27-32.

52. Philibert $A$, Ridde $V$, Bado A, Fournier $P$ : No effect of user fee exemption on perceived quality of delivery care in Burkina Faso: a case-control study. BMC Health Serv Res 2014, 14(1):120.

53. Mocumbi S, Högberg U, Lampa E, Sacoor C, Valá A, Bergström A, von Dadelszen P, Munguambe K, Hanson C, Sevene E et al: Mothers' satisfaction with care during facility-based childbirth: a cross-sectional survey in southern Mozambique. BMC Pregnancy and Childbirth 2019, 19(1):303.

\section{Figures}

Page 13/14 

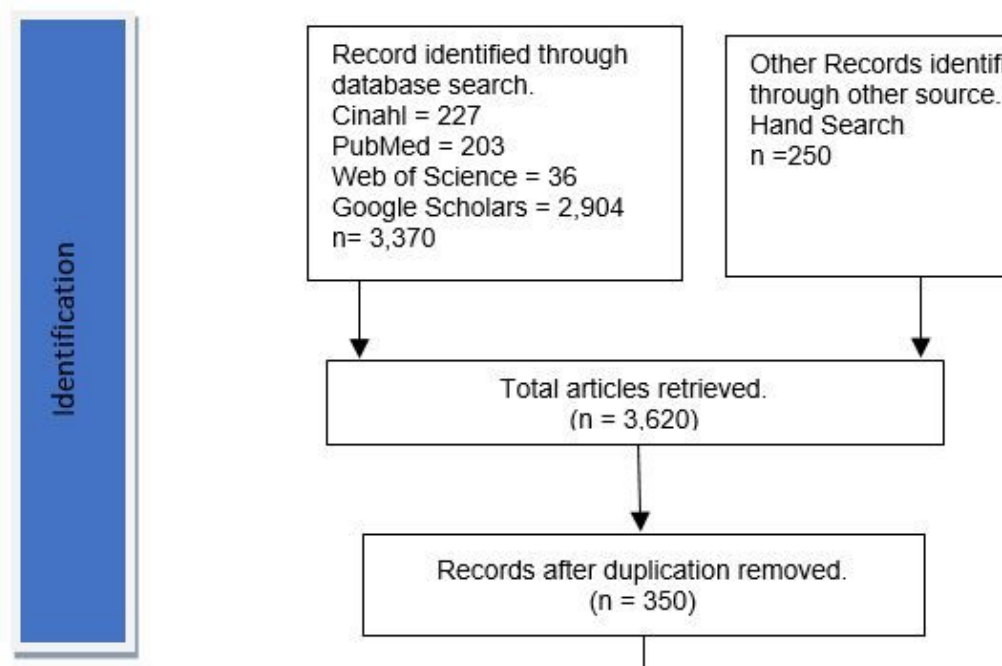

through other source.

$\mathrm{n}=250$
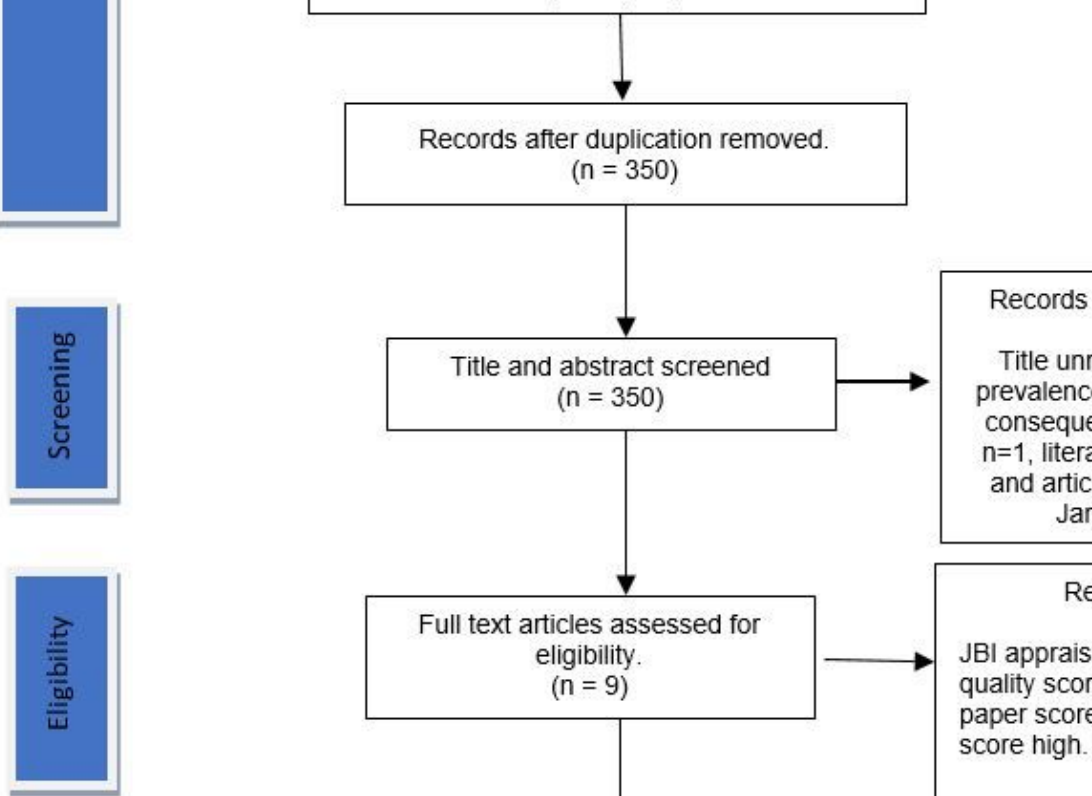

$(n=350)$

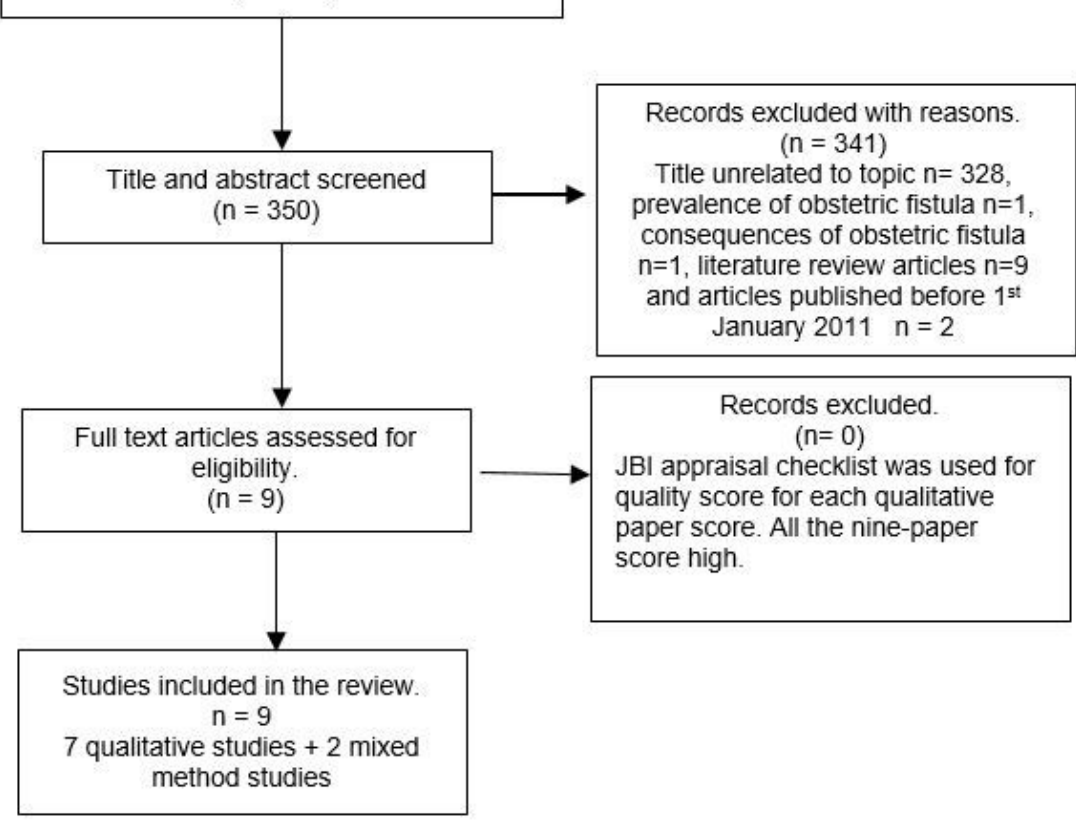

Figure 1

PRISMA flow diagram.

\section{Supplementary Files}

This is a list of supplementary files associated with this preprint. Click to download.

- Dataextractionthematicanalysis.docx

- JBICriticalApprisalChecklistForQualitativeReview.docx 